\title{
POR UMA ESCUTA LIVRE
}

Roberto Kittel Pohlmann ${ }^{1}$

José Estevam Gava ${ }^{2}$

\section{Resumo}

Este artigo discute a escuta musical livre, pela qual se promove o conhecimento musical e a audição do mais amplo leque de músicas, libertando o ouvinte, mesmo que parcialmente, com relação aos repertórios musicais divulgados e enaltecidos pelos meios de comunicação de massa. Como embasamento teórico e ponto de partida, são considerados aqui os trabalhos de Murray Schafer sobre a limpeza de ouvido e de Gaston Bachelard a respeito da noção de hábito. A partir desses autores em especial e de experiências docentes aqui relatadas, esboçam-se técnicas e estratégias para aplicar e incentivar formas de escuta musical alternativas, mais livres e críticas.

Palavras-chave: Música; Educação; Escuta Livre; Hábito; Musicaos - Música Sem Fronteiras

\section{INTRODUÇÃO}

Este artigo é fruto dos incômodos e inquietações que os meios de comunicação massivos provocam em mim, Roberto Pohlmann, ao delimitarem e restringirem a escuta musical das pessoas. Deliberadamente, ou não, esses meios de comunicação direcionam os ouvintes a um restrito leque de artistas e estilos, associando suas músicas a também uma restrita gama de sensações, emoções e sentimentos que podem advir dessa escuta limitadora.

\footnotetext{
${ }^{1}$ Mestrando em educação pela Universidade de Santa Cruz do Sul (UNISC). Licenciado em música pela Universidade Federal de Pelotas (UFPEL). Instrutor de artes do Programa Oficinas Culturais-Música, promovido pelo Serviço Social da Indústria (SESI). Endereço: Rua Manaus, 685, Bairro Schultz, CEP 96845-500, Santa Cruz do Sul/RS, Brasil. Tel. (51) 9595-9066. E-mail: robertopohlmann@ yahoo.com.br

${ }^{2}$ Bacharel em música, violonista, mestre em artes e doutor em história pela Universidade Estadual Paulista (UNESP). Professor Adjunto nível IV do Setor de Artes, Comunicação e Design da Universidade Federal do Paraná (UFPR). Endereço: Rua Coronel Dulcídio, 638, Bairro Batel, CEP 80420-170, Curitiba/PR, Brasil. Tel. (41) 3307-7303. E-mail: jotaest@uol.com.br
} 
Nesse processo, artistas e estilos musicais diferentes e alternativos, perdem a chance de divulgação diante dos modelos musicais adotados pelos grandes conglomerados midiáticos, modelos que têm em sua base preocupações apenas com o que é rentável, com o que tem mais chances de ser aceito prontamente pelo maior número possível de indivíduos (AGUIAR, 2008, p.30).

Meios de comunicação de massa ou mídias são entendidos aqui como aqueles veículos de informação e entretenimento que atingem parcelas majoritárias de uma população (CERQUEIRA, s/d, p.5). Os efeitos dessas mídias têm sido estudados e questionados desde a primeira metade do século $\mathrm{XX}$, haja vista seus potenciais para formar opiniões, padronizar hábitos, incutir gostos e incentivar posturas. Levando em conta a força com que esses meios de comunicação têm moldado a escuta musical, limitando-a, defendo aqui e demonstro a importância e necessidade de uma escuta musical livre, libertadora dos padrões musicais correntemente determinados. O contato com uma variedade de produções musicais é libertadora, pois permite às pessoas também conhecer novos instrumentos, capazes de produzir os mais diversos timbres e formas musicais e abrindo, enfim, múltiplas possibilidades em termos de sensações e emoções que podem advir desse tipo de escuta consciente e alternativa. Esse tipo de escuta, que aqui denomino escuta livre, em tese proporciona sensações distintas justamente porque pode apresentar novidades a cada audição.

Este artigo tem por intuito discutir a escuta livre, tipo de experiência que promove um enriquecimento no ato de ouvir; o desenvolvimento de novas sensibilidades tanto pelos variados sons que cercam as pessoas como pela produção musical, sobretudo aquela mais livre dos padrões da indústria fonográfica. Para tanto, recorro às ideias de Murray Schafer, detendo-me principalmente nos conceitos de limpeza de ouvido, paisagem sonora, ruído e silêncio. Recorro também às noções de hábito, segundo Gaston Bachelard, experiência, segundo Jorge Larrosa e técnica, segundo Humberto Galimberti, principalmente. Apresento e discuto, ainda, algumas de minhas experiências profissionais que se relacionam diretamente com os conceitos aqui discutidos e, em especial, com a noção de escuta livre. Um recurso do qual tenho me utilizado e que está disponível às pessoas em geral consiste no programa radiofônico Musicaos- música sem fronteiras. Com este recurso procuro indicar e sugerir caminhos que possam ser utilizados pelo educador musical que deseje promover a escuta livre com seus alunos. 
Para iniciar a discussão aqui proposta, considero importante partilhar a primeira experiência que tive ao ouvir músicas fora do padrão midiático. Essa experiência ocorreu no início de minha trajetória profissional com música, durante uma das primeiras aulas do curso de graduação. Lembro-me de ter entrado numa sala de aula, pouco iluminada, numa manhã de abril. Logo reparei nas cadeiras velhas dispostas em semicírculo, no quadro negro desenhado com pautas musicais e no piano de armário empoeirado que sustentava um pequeno aparelho de som. Reparei também nos outros alunos que, assim como eu, demonstravam um misto de ansiedade e apavoramento diante do professor que, muito compenetrado, folheava o que parecia ser o encarte de um disco. Pontualmente, às oito e trinta da manhã, o professor se levantou; muito calmamente se apresentou e nos desejou boas vindas à disciplina de teoria musical e percepção auditiva. Em seguida, ele nos disse que daríamos início a um ritual de audição e discussão que seria feito no início de todas as aulas da disciplina e ao qual ele se referia como operação cotonete ou de limpeza de ouvidos. Assim foi durante os quatros semestres seguintes.

Naquela primeira aula ouvimos três temas musicais. Os dois primeiros foram do grupo paulistano Os Mulheres $\mathrm{Negras}^{3}$ e se intitulavam Etiópia mirim e A lavadeira, o varal e a saudade. Em seguida, ouvimos a polifonia vocal Le chant des oiseaux, de Clement Janequin ${ }^{4}$. Durante a audição, em alguns momentos quis dançar, em outros me foram despertados sentimentos intensos os quais não encontro palavras para descrevê-los. Noutros momentos, eu pensava no que teria levado os compositores a criarem tais músicas; como as teriam feito e com qual finalidade. Terminada a audição, olhei para os colegas e me pareceu que eles haviam tido reações e inquietações semelhantes às minhas, pois permaneceram em silêncio, apenas na expectativa de como seria a continuidade da aula. Todos aguardavam o que professor diria ou faria em seguida. Ele fez, então, uma série de considerações históricas pertinentes às músicas que acabáramos de ouvir, o que, por si só, ajudaram a abrandar várias das inquietações que aquele breve experimento musical havia causado em mim e, por certo,

\footnotetext{
${ }^{3}$ Os Mulheres Negras é um grupo paulista formado por André Abujamra e Maurício Pereira. Autointitulados como a terceira menor big band do mundo, causaram enorme agitação no "submundo" musical paulista da década de 80 ao dividir o palco com um enorme amontoado de fios e equipamentos eletrônicos. Graças a isso os dois soavam como uma banda completa. Sua discografia é composta por dois discos: Música e ciência (1988) e Música serve pra isso (1990). Atualmente, os músicos alternam as apresentações do grupo com trabalhos independentes.

${ }^{4}$ Clement Janequim (1485-1558) foi um compositor francês do período renascentista, muito conhecido por sua produção de canções e pelo desenvolvimento da polifonia vocal. Tornou-se conhecido no seu país de origem ao compor a música da entrada do rei Francisco I da França na cidade de Bordeaux. Sua obra ainda é muito interpretada por coros, sendo inclusive estudadas em universidades brasileiras, por exemplo.
} 
nos demais alunos. Em seguida, o professor perguntou se a turma considerava importante a audição de músicas diferentes e variadas em sala de aula. Como a resposta foi unânime e afirmativa, o professor quis saber por quê. Novamente o silêncio pairou na penumbra da sala. Todos procuravam explicações racionais para justificar a importância da audição musical na prática docente. Quebrando o silêncio, uma voz fraca e hesitante se atreveu a responder a pergunta com outra pergunta: seria para aumentarmos nosso conhecimento sobre estilos musicais? Prontamente, todos concordaram a resposta, aliviando a ansiedade do colega corajoso. Com o aprofundamento das discussões, a turma concluiu que era preciso que todos tivessem acesso à vasta produção artística mundial e não apenas a uma pequena e prédeterminada fatia dela. Também foi consensual a ideia de que os professores de música deveriam ser os embaixadores dessa empreitada, que deveria ser promovida a partir de audições como essa que acabei de descrever, contextualizada e debatida, com informações sobre os compositores, os intérpretes e os estilos, enfim, sobre toda a riqueza, diversidade musical e informação disponível hoje em dia. Todos concordaram que isso alargaria e enriqueceria em muito a experiência com a música, tanto intelectual como sensorialmente e que, por certo, essa postura ajudaria a romper com os fortes limites impostos pelos meios de comunicação de massa. Por fim, todos também concordaram que apenas em etapas posteriores é que deveriam se dar as abordagens propriamente técnicas, os primeiros contatos com as maneiras e recursos disponíveis para se produzir música. Em resumo, tudo começaria com a audição.

Assim foi meu primeiro dia de aula na universidade, especificamente no curso de licenciatura em música na Universidade Federal de Pelotas. Esse breve evento despertou em mim grande interesse pela escuta livre, pois a partir de então percebi o quanto eu estava preso e delimitado pelo que os grandes meios de comunicação veiculavam. Ou seja, mesmo já atuando profissionalmente na área, o meu trânsito no campo musical era bastante restrito. Como provavelmente era a intenção do professor naquele primeiro encontro, prontamente alterei minha forma de ouvir música e questionei: será que os sentimentos e sensações que me vêm ao ouvir música são reais e genuínos ou são meramente aquilo que a indústria fonográfica quer que eu sinta? Será que essa indústria não está direcionando minhas reações de acordo com a música que ela quer que eu compre e ouça? Percebendo a necessidade de conhecer mais para, assim, enriquecer minhas experiências ao ouvir música, passei a buscar a 
POHLMANN, K. R.; GAVA, J. E.

maior diversidade possível de compositores e intérpretes, dos mais variados estilos. Como um militante por essa causa musical, senti que devia compartilhar minhas descobertas com os outros, levando a que mais pessoas alargassem suas escutas musicais, abrindo seus ouvidos a sempre novas possibilidades.

Ainda durante meu curso de graduação em música e por iniciativa do mesmo professor aqui referido, foi criado um projeto de extensão cuja finalidade era justamente a de dar uma pequena amostra da grande diversidade musical disponível hoje ao maior número possível de pessoas. Refiro-me ao programa radiofônico Musicaos- música sem fronteiras, que está em atividade até hoje, do qual foi um dos primeiros integrantes e que apresento mais detalhes no decorrer deste artigo. Gostaria, antes disso, de tecer algumas considerações sobre o autor que me forneceu os primeiros amparos teóricos para desenvolver estas reflexões: o educador musical Murray Schafer.

\section{PAISAGEM SONORA E LIMPEZA DE OUVIDOS}

Murray Schafer, nascido no Canadá em 1933, musicólogo, pedagogo e compositor, tem tido suas ideias bastante estudadas e debatidas. Dentre seus conceitos mais interessantes e oportunos constam aqueles a respeito da paisagem sonora e da limpeza de ouvidos, explanados na obra $O$ ouvido pensante. Nessa obra encontrei aporte teórico relativo às minhas inquietações, bem como relatos de experiências vividas por aquele autor em sua prática educativa e em sua busca pelo autoconhecimento. Murray Schafer sugere e recomenda a escuta atenta dos sons do ambiente; a percepção das múltiplas sonoridades que nos rodeiam, incluído os ruídos e timbres que, contudo, a educação formal e informal nos ensina a ignorar e entender como não-música. Logo na apresentação da obra, a tradutora, Marisa Trench de Oliveira Fonterrada, alerta para o fato de que "o livro se apresenta como um mundo a descobrir, pois questiona a aceitação desprovida de reflexão crítica, incita o leitor a buscar novas ideias, a desconfiar de suas certezas e a aprender a reconhecer em suas dúvidas a motivação de querer saber", dando uma ideia da amplitude e enorme riqueza dos temas que aguardavam pelo leitor (2011, p.12).

Alguns dos relatos do livro têm muito a contribuir com a discussão da escuta livre. Ao ser convidado para fazer parte de um grupo de ensino do North York Summer Music School, no ano de 1964, por exemplo, Murray Schafer, entre outras perguntas inquietantes, lançou a 
questão: o que é música? Segundo ele, uma das piores coisas que podem acontecer na nossa vida é fazermos coisas sem saber bem o que elas são ou as razões que nos levam a fazê-las. Depois de muita discussão, o autor conclui que música é uma organização de sons com a finalidade de ser ouvida (ibidem, p.13). Sendo assim, pode-se dizer que tanto J. S. Bach quanto Tom Zé $\mathrm{e}^{5}$ fazem música. Se ela agrada determinadas pessoas, ou não, isso decorre de sentimentos, sensações e questões particulares que não devem ser julgadas. Cabe ao educador unicamente, tornar essas escutas possíveis ao maior número de ouvintes.

Do mesmo livro, outra passagem que merece destaque se encontra no Capítulo II, a respeito da limpeza de ouvido. $\mathrm{O}$ autor relata a experiência que teve durante um curso de música experimental oferecido a alunos ingressantes na Universidade Simon Fraser. Segundo ele, a primeira tarefa naquele curso seria a de abrir ouvidos, sempre levando os alunos "a notar sons que na verdade nunca haviam percebido, ouvir avidamente os sons de seu ambiente e ainda os que eles próprios injetavam nesse ambiente" (ibidem, p.55). O autor segue explicando que esse foi o motivo pelo qual seu curso se intitulou limpeza de ouvidos, pois antes do treinamento propriamente dito seria preciso reconhecer a necessidade de limpar os ouvidos. Esses órgãos realizam operações extremamente delicadas e essenciais para nosso organismo e, ao contrário de outros órgãos dos sentidos, os ouvidos são expostos e vulneráveis, sempre abertos a estímulos externos. Por esses motivos e especialmente para os estudantes de música, músicos e ouvintes conscientes, a limpeza dos ouvidos é primordial.

Schafer (1991) também aborda e discute a noção de ruído, conceito que muitas vezes serve para qualificar a música de compositores que fogem aos padrões do que seja música. No senso comum, dizer que algo não é música, mas ruído, barulho, é atitude bastante corriqueira. A relação aí estabelecida se baseia na definição há séculos estabelecida sobre o que é ou não é música. Por essa definição, música é diferente de ruído e ruído é entendido como som indesejável. "Para os insensíveis, o conceito de ruído não é válido. Alguém que dorme como uma pedra não ouve nada. A máquina é indiferente ao ruído porque não tem ouvidos. Explorando essa indiferença, a música de fundo foi inventada para homens sem ouvidos"

\footnotetext{
${ }^{5}$ Tom Zé é baiano de Irará, cognominado O Maldito, formou-se na Escola de Música da Bahia e participou do LP Tropicália ou panem et circenses, de 1968, juntamente com Caetano Veloso, Gilberto Gil, Gal Costa, Nara Leão, Rogério Duprat, Capinam e Torquato Neto. O tropicalismo é considerado o movimento artístico-musical que sucedeu a bossa nova em termos de importância e originalidade. Tom Zé gravou e recebeu vários prêmios no exterior. Ele conta com mais de 25 álbuns já lançados e continua na ativa com suas atuações irreverentes, únicas e instigantes.
} 
(ibidem, p.56-57). Por exemplo: quantas vezes vamos ao supermercado e percebemos que havia música ambiente apenas no momento de pagar a conta? Era música que não escolhemos ouvir, mas, no fim das contas, saímos da loja cantarolando uma canção de artista desconhecido. A indústria fonográfica e muitas práticas sociais correntes acarretam às pessoas audições compulsórias. São ruídos que nos fazem perder a capacidade de escolha sonora, de liberdade auditiva, criando em nós o hábito de receber e aceitar informações sonoras sem questionar sua qualidade, necessidade e finalidade.

Uma vez constatada essa perda de liberdade auditiva, quais seriam as alternativas? Haveria como as pessoas lutarem para reaver esse direito há muito perdido? Nesse sentido, gostaria de expor experiências que venho tendo ao longo de minha trajetória como professor de música e que têm se mostrado muito interessantes e válidas. Em especial quero relatar minha participação no programa radiofônico Musicaos- música sem fronteiras.

\section{MUSICAOS - MÚSICA SEM FRONTEIRAS}

Musicaos- música sem fronteiras é um programa radiofônico que teve início no ano de 2008 na Universidade Federal de Pelotas, na forma de projeto de extensão aberto à participação da comunidade acadêmica e toda a coletividade. Tive a oportunidade de integrar a equipe de produção do Musicaos- música sem fronteiras durante três anos. Ao longo desse período pude contribuir para a divulgação de repertórios musicais incomuns, compositores e intérpretes pouco conhecidos do público em geral, bem como explorar o chamado "lado B" de alguns discos, que contém músicas normalmente menosprezadas pelas emissoras de rádio comerciais.

O programa Musicaos- música sem fronteiras não tem fins lucrativos e até o presente momento é transmitido por três emissoras universitárias do Rio Grande do Sul: a Rádio Federal FM, de Pelotas, a Rádio Universidade AM, de Santa Maria, e a FURG FM, da cidade de Rio Grande. No contexto do projeto já foram produzidos e transmitidos, até a data de redação deste artigo, cerca de 150 programas sobre os mais diversos e variados temas, de música guarani ${ }^{6}$ até clássicos da atualidade, como o compositor Philip Glass ${ }^{7}$. Com o objetivo

\footnotetext{
${ }^{6}$ Segundo informa a página do Musicaos- música sem fronteiras na internet, a música guarani é de tradição milenar, faz parte de uma concepção religiosa do mundo. Para os índios guaranis, o canto e a palavra são desdobramentos da essência divina de Nhanderu, nosso primeiro pai, criador de tudo que existe. Assim, canto e
} 
de "tocar tudo, menos os sucessos da hora", o programa Musicaos- música sem fronteiras é uma ferramenta que tenho utilizado com meus alunos para a divulgação e análise de estilos musicais diferentes. Ouvindo cada edição se tem um pouco da biografia dos compositores e intérpretes, seus momentos históricos, questões de estilo e estética musical.

Tendo eu atuado como produtor e apresentador do programa Musicaos- música sem fronteiras, possuo o acervo completo e proporciono aos meus alunos de um projeto de educação continuada, a audição semanal de um programa Musicaos- música sem fronteiras, novo ou antigo. É evidente que um programa de rádio como esse não foi a única ferramenta de trabalho que me ocorreu, mas foi aquela que adotei como ferramenta principal em razão da praticidade e pelo fato de eu ter colaborado em sua realização.

Além das transmissões por ondas de rádio, em AM e FM, os programas Musicaosmúsica sem fronteiras podem ser ouvidos on-line, em tempo real. O projeto Musicaos conta também com uma página na internet pela qual se têm várias informações sobre o programa (http://programa-musicaos-programas.blogspot.com.br/). Ali se encontra a relação dos temas já abordados e as resenhas de alguns programas, por exemplo. Contudo, a página é apenas um adendo, pois o público-alvo é o ouvinte de rádio tradicional, amplo e indistinto, ao qual se pretende alargar a cultura musical e libertar os ouvidos ainda fortemente presos aos modelos e repertórios elegidos pela indústria cultural, ao longo de décadas. A essência do projeto Musicaos é despertar curiosidade, espanto e questionamentos por intermédio de, espera-se, novas experiências musicais e sonoras. Essa ferramenta tem sido utilizada por mim como técnica de desenvolvimento vinculada aos conceitos de hábito e experiência.

\section{A NOÇ̃̃o DE HÁBITO SEGUNDO GASTON BACHELARD}

palavra são canais de comunicação direta com os deuses; têm o poder de curar as pessoas e fortalecer a vida comunitária. http://programa-musicaos-resenhas.blogspot.com.br/. Acesso em 27 jan. 2014.

${ }^{7}$ Dentre os compositores dos, assim chamados, clássicos da atualidade, Philip Glass é um dos mais aclamados. De origem norte-americana, ele é conhecido principalmente por suas trilhas sonoras de cinema, nas quais utiliza uma técnica de composição comumente chamada minimalismo (técnica que consiste em utilizar a repetição insistente de intervalos e pequenos motivos musicais). Glass tem algumas produções musicais relacionadas ao Brasil. Ele compôs obras como Itaipu (1989), feita para a usina hidrelétrica de mesmo nome, com destaque para a letra em língua guarani e a obra Days and nights in Rocinha (1997), feita para a favela Rocinha, depois de uma visita ao local. Também compôs os temas do disco Águas da Amazônia (1999) do grupo mineiro Uakti. Sua produção é ampla e sua estética, ainda que controversa, tem razoável aceitação por grande parcela do público. 
POHLMANN, K. R.; GAVA, J. E.

Gaston Bachelard pode ser considerado um dos grandes pensadores do século XX e sua obra contribui de forma significativa para a epistemologia da filosofia. As reflexões aqui desenvolvidas e apresentadas ancoram-se na obra A intuição do instante, publicada em 1932. Nesse trabalho Gaston Bachelard desenvolve a teoria de Gaston Roupnel acerca do tempo descontínuo, ou seja, acerca de instantes, opondo-se às teorias de Henri Bergson, que entende o tempo como uma duração contínua. Aqui, me deterei no segundo capítulo, intitulado $O$ problema do hábito e do tempo descontínuo, o qual trata do hábito e o define como a assimilação rotineira de uma novidade (2011, p. 62). A delimitação de hábito fornece a noção de uma das técnicas a ser empregada para se atingir uma escuta liberta: a técnica da repetição. Neste caso, vale a pena frisar que a técnica é entendida segundo Humberto Galimberti, que a define como aquilo que funciona, ou seja, a maneira pela qual se faz alguma coisa de modo eficiente com vistas a um propósito bem definido (2006, p.8). Reforçando essa ideia, eu diria que após reconhecer a importância de uma escuta liberta, bem como de sua promoção, é preciso uma técnica para o ensino da liberdade auditiva. Assim sendo, a técnica que penso ser eficaz para o desenvolvimento em sala de aula consiste na audição do programa Musicaosmúsica sem fronteiras ou de qualquer outro repertório no início de cada aula, sempre tendo em mente a ideia de novidade, surpreendendo o aluno a cada audição. Essa técnica é o que Bachelard entende como processo de assimilação do hábito. Nas palavras do autor, "um hábito particular é um ritmo sustentado, no qual todos os atos se repetem igualando com bastante exatidão seu valor de novidade, mas sem jamais perder esse caráter dominante de ser uma novidade. A diluição do novo pode ser tamanha que, às vezes, o hábito pode passar para o inconsciente" (2007, p. 66).

Esse hábito particular de que fala Bachelard é entendido, aqui neste trabalho, como o da escuta livre. A cada encontro, a promoção da escuta livre deve ser provocadora para não ser assimilada de forma inconsciente. Desta forma, se mantêm os questionamentos e as sensações instigadas pela novidade musical, diferentemente da escuta compulsória e desatenta proporcionada por música ambiente em locais públicos, por exemplo. Nesse sentido, é desaconselhável repetir um programa ou determinadas músicas a ponto de se diluir a escuta, tornando-a inconsciente. Portanto, o que deve ser repetido é o hábito da escuta livre, o hábito de escutar percebendo a novidade, e não determinadas músicas.

Ainda sobre esta técnica de trabalho, é importante considerar o tempo necessário para que a escuta se torne um hábito. De fato, não há um consenso entre os pesquisadores em relação ao tempo de assimilação de um hábito, já que todo ser humano é singular. Todavia, 
em minha prática educativa percebi que essa experiência deve ser promovida por no mínimo seis meses para que os alunos a repitam fora do contexto e do espaço da sala de aula. $\mathrm{O}$ conceito de experiência a que me refiro segue a concepção de Jorge Larrosa que a define como aquilo que nos acontece, conforme o significado etimológico da palavra (2002, p. 21). No decorrer dessa prática, dessas experiências, há possibilidades de os alunos se sentirem fatigados com a rotina estabelecida. A contextualização dos exemplos musicais, o destaque para questões históricas, a descrição dos instrumentos utilizados, os efeitos que a música provoca e todas as discussões decorrentes são pertinentes à prática em questão, ainda que, obviamente, nem todos os alunos as aceitem, tolerem ou valorizem de pronto. Nestes casos, explico-lhes que eles estão vivenciando um processo de desintoxicação auditiva com o objetivo de rever conceitos já estabelecidos, esclarecer questões culturais, analisar e discutir gostos pessoais e pensar como esses gostos e hábitos são construídos. Segundo Larrosa, a impaciência em qualquer processo de aprendizagem provém da agitação e imediatismo inerentes à vida contemporânea. Esse ritmo acelerado muitas vezes, rouba a chance de que algo nos aconteça, dificultando ou mesmo impedindo a concretização de certas experiências (2002, p. 23). Por isso, ao professor é exigido que tenha calma e perseverança na aplicação dos exercícios com os alunos. A propósito, em seguida, partilho a experiência da promoção da escuta no contexto em que atuo, narrando os percalços e as boas surpresas que tenho tido ao desenvolver esse processo.

\section{MUSICAOS-MÚSICA SEM FRONTEIRAS EM SALA DE AULA}

Atualmente, leciono no programa de educação continuada Oficinas Culturais SESI Música, promovido pelo Serviço Social da Indústria na cidade de Santa Cruz do Sul. Historicamente, o programa iniciou suas atividades nessa cidade, em março de 2012, com a contratação de dois profissionais, eu e outro instrutor, e continua em atividade até o momento atual. Esta é minha primeira experiência profissional em projetos de educação continuada, tendo antes passado por um período de adaptação. As Oficinas Culturais se ancoram em um projeto político pedagógico estruturado e organizado em nível estadual por intermédio de módulos e níveis. São três os módulos, cada qual com suas especificidades. 
No Módulo I, se inscrevem alunos de sete a dez anos de idade que são atendidos uma vez por semana, em turno oposto ao escolar, durante três horas, incluindo o horário para lanche. Este é o único módulo que não é dividido em níveis. O Módulo II atende a alunos com idades entre 11 e 17 anos inscritos em vários níveis: I e II (básicos), III e IV (intermediários) e V e VI (avançados). Cada nível dura aproximadamente seis meses e o aluno avança conforme seu progresso quanto à compreensão e domínio do conteúdo estudado e retrocede conforme suas dificuldades. Assim, a mudança de nível se dá conforme o processo de assimilação do conteúdo, motivo pelo qual o aluno pode imediatamente ser trocado de nível, caso suas dificuldades sejam vencidas. O aluno pode também retroceder por livre iniciativa, se perceber que precisa de um reforço em determinado conteúdo. Os alunos comparecem à instituição duas vezes por semana, para realizar um total de seis horas de atividades, também em turno oposto ao escolar. No Módulo II, o aluno participa de três oficinas: teoria musical e percepção auditiva, instrumento e prática instrumental. Este módulo tem a particularidade de que os alunos são levados a integrar uma banda marcial que já existia em Santa Cruz do Sul, antes mesmo do nascimento do programa de educação continuada do SESI. O aluno precisa estar matriculado e cursando as oficinas para ingressar na banda. O Módulo III é voltado para alunos com idade igual ou superior a 18 anos que sejam trabalhadores da indústria. As aulas de uma hora e meia de duração são noturnas e acontecem uma vez por semana. Neste módulo é oferecida uma oficina de violão, conforme os mesmos níveis do Módulo II.

Como se pode perceber, o programa possui algumas diretrizes: divisão em módulos e níveis e delimitação das disciplinas a serem trabalhadas. No entanto, não há uma delimitação curricular para a abordagem dessas disciplinas, de modo que há margem para os instrutores comporem o currículo do projeto ao longo de sua prática educativa, elegendo e julgando o que pensam ser importante para o grupo de determinada cidade, respeitando, assim, a característica de cada região. Nesse contexto, fiquei responsável pelas oficinas de teoria musical, prática de conjunto e violão, enquanto que o outro instrutor se encarregou da regência da banda marcial e do ensino de instrumentos de sopro das famílias das madeiras e dos metais.

As experiências que relato em seguida se deram ao longo dos anos de 2012 e 2013 com os alunos do Módulo II do referido programa de educação continuada. O grupo continha 30 alunos divididos em dois turnos, manhã e tarde, de acordo com o projeto político pedagógico. Inicialmente, os alunos vieram a ingressar no programa Oficinas Culturais em virtude da banda marcial, que já existia anteriormente, e que é motivo de orgulho para o 
bairro, conferindo ao participante considerável importância perante a comunidade. A Banda Marcial do SESI é considerada pela instituição como um grupo artístico e possui diretrizes próprias, tendo o objetivo de propiciar ao aluno a prática musical, experimentando em apresentações públicas o repertório estudado em sala de aula. A banda marcial reúne os alunos dos dois turnos e os ensaios ocorrem à noite.

$\mathrm{Na}$ primeira conversa com o grupo, tomei conhecimento de que alguns alunos que já tocavam na banda não haviam cursado aulas regulares. Desse modo, muitas etapas do processo de ensino deixaram de ser cumpridas, como, por exemplo, os elementos básicos de notação musical, a ponto de os alunos terem a partitura, mas não saberem lê-la. Além disso, o repertório era formado por músicas “do momento", ou seja, aquelas mais divulgadas pela mídia. Prevalecia também um espírito imediatista pelo qual uns poucos ensaios já deveriam resultar em apresentações públicas, obviamente com prejuízo técnico-musical. Em função dessas circunstâncias, a instituição concordou em permitir o ingresso e permanência do aluno na banda marcial apenas se ele cursasse as matérias do programa: teoria musical e percepção auditiva, prática de instrumento e prática de conjunto.

Logo no início de minhas atividades, como experimentação, selecionei diversos materiais com o objetivo de promover escutas livres. Lembro-me de que os primeiros exemplos musicais que escolhi haviam sido compostos pelo acordeonista gaúcho Aluísio Rockemback $^{8}$. Durante a audição, alguns alunos riram. Percebi, também, que vários alunos se entreolharam como que buscando pistas para formar juízos a respeito do que se ouvia, aceitando ou rejeitando a música. A minha intervenção se deu por intermédio de informações básicas a respeito do material recém-ouvido. Em seguida, coloquei algumas questões aos alunos. Primeiramente, indaguei se eles conheciam o artista e se tinham o hábito de ouvir música instrumental. A resposta foi negativa para ambas as questões. Então, perguntei os tipos de música com os quais eles tinham mais afinidade ou aqueles que mais ouviam. Como resposta obtive nomes de uns poucos artistas, em torno de três, mais especificamente Luan Santana, Ivete Sangalo e Gustavo Lima, unanimemente conhecidos e ouvidos por todos os alunos presentes. Logo notei que as preferências musicais daqueles alunos diziam respeito a cantores, compositores e músicos com forte presença nos meios de comunicação de massa,

\footnotetext{
${ }^{8}$ Aluísio Rockembah é acordeonista, arranjador, compositor e produtor musical. Natural de Pelotas-RS, Aluísio lançou seu primeiro disco em 2009, intitulado Santa flor, nesta obra ele mescla os ritmos latinos com uma linguagem jazzística repleta de nuances particulares.
} 
rádio e TV. Por esse motivo, por essa evidente delimitação de nomes e estilos musicais, decidi iniciar os trabalhos de teoria musical e prática de conjunto com um processo de libertação auditiva.

Escolhido o ponto de partida, recorri às teorias de Murray Schafer e, mais tarde, de Gaston Bachelard. Durante essas leituras, lembrei-me dos programas de rádio Musicaosmúsica sem fronteiras, aqui já mencionado, e percebi o quanto eles poderiam me auxiliar nas aulas. Dei prontamente início a práticas semelhantes àquelas sugeridas por Murray Schafer no livro $O$ ouvido pensante. Utilizei, em aula, indagações a respeito do que é música, o que é som e o que é silêncio, por exemplo. Com o debate, alguns conceitos foram se definindo, e no final chegamos a conceituação conforme Schafer (1991, p.23), qual seja, música é uma organização de sons e silêncios com a intenção de serem ouvidos. Som foi entendido como o material sonoro produzido pelo homem através de instrumento musical ou outro dispositivo, enquanto que silêncio, como a ação deliberada de não produzir qualquer som em certo momento de uma peça musical. Estas e outras definições continuaram a ser repensadas, debatidas e melhoradas conforme os alunos foram tendo contato com uma maior quantidade e diversidade de composições musicais.

Ao longo de 2012 e 2013, fizemos audições de programas Musicaos- música sem fronteiras duas vezes por semana. No início, a apresentação do material sonoro era seguida por risos e até gargalhadas dos alunos. Gradativamente, porém, as manifestações de chacota foram diminuindo. Transcorridos aproximadamente seis meses, o riso da maioria dos alunos foi substituído por indagações e relatos acerca das sensações que determinadas músicas provocavam. Quando ouvimos a interpretação de Richard Galliano ${ }^{9}$ para as Quatro estações portenhas, de Astor Piazzolla ${ }^{10}$, por exemplo, a música causou sensações pertinentes ao clima e à cultura gaúcha. Segundo os alunos, a composição de Piazzolla foi mais eficiente em sugerir tais sensações do que As quatro estações, de Antônio Vivaldi, também ouvida e comparada em termos estéticos. Noutro momento, assistimos ao programa Encuentro en el

\footnotetext{
${ }^{9}$ Richard Galliano é um acordeonista francês, muito conhecido por suas composições, interpretações e por sua técnica apurada. Galliano contabiliza mais de 20 discos em sua carreira e a obra mencionada neste artigo, As quatro estações portenhas, faz parte do disco Piazzolla Forever de 2003, o qual interpreta com excelente bom gosto as composições de Astor Piazzolla.

${ }^{10}$ Astor Piazzolla (1921-1992) é considerado um marco na música latino americana, ao reinventar o modo de se fazer tango bem como de tocar bandoneón, seu instrumento de origem. Dono de um modo único de composição, mesclando formas clássicas ocidentais, jazz e música latino-americana, sua obra é estudada no mundo todo até os dias atuais.
} 
estudio com a companhia de murga Falta e Resto ${ }^{11}$. Os alunos gostaram muito da audição, tanto que vários até manifestaram, jocosamente, interesse em se mudar para o Uruguai.

A audição, apreensão e progressiva maior aceitação de repertórios musicais diversificados e incomuns viabilizou a que diversos estilos musicais pudessem ser trabalhados nas aulas de prática de conjunto, colocando os alunos no manejo de ritmos e vivências musicais mais amplas, como quando executamos o samba História de um valente, do compositor K-Ximbinho ${ }^{12}$, ou o clássico do jazz, Blue bossa. Depois de um período de aproximadamente um semestre dessa prática de conjunto, os alunos se tornaram mais seguros quanto à compreensão da música como linguagem e forma de expressão e às práticas musicais desenvolvidas no projeto. Eles também passaram a opinar mais sobre os arranjos e a instrumentação. Desenvolveu-se, assim, uma maior autonomia com relação a ouvir, tocar e pensar sobre música.

Com o avanço dos trabalhos, os alunos passaram a exercer seus dotes criativos, especialmente em ocasiões em que estudamos a estrutura de um standard de jazz e de repertórios latino-americanos. Esse aprofundamento fez com que os próprios alunos passassem a sugerir repertórios bem diferentes daqueles praticados pelos meios de comunicação de massa comerciais. Os alunos aprenderam a reconhecer e apreciar artistas até então inéditos para a maioria deles, como o violonista Yamandu Costa, o saxofonista Charlie Parker $^{13}$, o multi-instrumentista Hermeto Pascoal e vários outros. Além disso, segundo relatos dos alunos, eles mesmos passaram a sugerir aos seus familiares o hábito da escuta liberta, privilegiando artistas diferentes e escutas mais amplas, livres e conscientes. Primeiramente isso se deu de forma indireta, passiva, pelo simples ato de estudarem os repertórios em suas casas. Aos poucos, a curiosidade e o interesse dos pais foram sendo despertados e os alunos se tornaram multiplicadores das práticas de sala de aula, estendendo ao ambiente doméstico as premissas da escuta livre.

\footnotetext{
${ }^{11}$ Falta e Resto é uma companhia de murga uruguaia que conjuga as harmonias peculiares do estilo com polifonia vocal, ritmos percussivos e fantasias irreverentes. Em sua grande maioria, as murgas fazem referência a temas políticos e sociais, denunciando desigualdades sociais, abusos políticos e outras questões.

12 K-Ximbinho (1917-1980) é o nome artístico de Sebastião de Barros, compositor, arranjador, clarinetista, saxofonista e regente. Nascido em Taipu, Rio Grande do Norte, K-Ximbinho foi diretor da Orquestra Tabajara e atuante na Orquestra do Maestro Fon-Fon. Como compositor gravou mais de 15 discos em que predominam dois estilos muito apreciados por ele, choro e jazz.

${ }^{13}$ Charlie Parker (1920-1955) foi um virtuose do saxofone. Ícone do jazz, Parker foi um dos desenvolvedores do estilo bebop, ramo jazzístico caracterizado especialmente por ampla e arrojada experimentação harmônica. Com vasta discografia, por muitos ele é tido como um dos maiores gênios da história da música do século XX.
} 


\section{CONSIDERAÇÕES FINAIS}

Sabe-se que a educação, as informações e os valores adquiridos durante a infância e a adolescência, quando nossa personalidade está em formação, são essenciais e decisivos para o resto de nossas vidas. Quando submetidos somente aos apelos dos meios de comunicação de massa comerciais, crianças e adolescentes são moldados com base no que esses meios priorizam, em geral fechando-se para novos conhecimentos ou vivências de panoramas artísticos e culturais mais amplos, diversificados e críticos. No caso específico da música, modalidade artística omnipresente na contemporaneidade, e por isso mesmo, é essencial que haja uma educação voltada a oferecer a mais ampla variedade de experiências estéticas e

sensoriais. É essa a bagagem de experiências que definirá nossas visões de mundo, nossos valores, nossos gostos pessoais legítimos e nosso senso crítico diante do que as grandes mídias nos apresentam.

Com este artigo procurei relatar minhas práticas docentes e como elas têm motivado os alunos a buscarem alternativas para o forte direcionamento, e consequente restrição, que a indústria cultural acarreta ao divulgar uma reduzida quantidade de artistas e estilos musicais. A indústria fonográfica, em especial, pressionada e determinada por questões de mercado, acaba por reforçar e ditar padrões de consumo, comportamento, linguagem e pensamento. Com essa prática, a indústria da música, deliberadamente ou não, impede ou dificulta as pessoas de acessar o vasto universo de sons que as inúmeras culturas e nichos musicais produziram ao longo dos séculos e continuam a produzir. Como resultado, essa limitação tem efeitos restritivos na formação estética e crítica das pessoas, bem como em suas capacidades de perceber, considerar, aceitar e vivenciar a novidade, o desconhecido.

A imediata aceitação e consumo de trabalhos de artistas estrangeiros no Brasil, notadamente aqueles produzidos nas economias centrais e de presença constante nos meios de comunicação de massa, demonstra o forte poder de padronização ancorado pelo capital. Apenas uma restrita parte da população brasileira compreende suficientemente e domina o idioma inglês. No entanto, o consumo de canções pop em idioma inglês é intenso e acrítico. O sucesso das cantoras Lady Gaga e Beyonce entre nós, por exemplo, confirma isso. Pode-se constatar que, como cantoras, elas nada acrescentam e que, em termos estéticos, suas canções apenas reproduzem padrões, clichês melódicos, expressivos e harmônicos. No entanto, graças 
a forte aparato de divulgação, amparado especialmente na visualidade e atuação cênica das cantoras, elas são vendidas e aceitas como o que de melhor se realiza na atualidade; o que deve ser "consumido" e cultuado.

Como músico e educador, vivencio diariamente o bombardeio de padrões e valores dos quais crianças e adolescentes são alvos pela TV, pelo rádio e pela internet (ainda que o acesso a essa mídia digital ainda seja restrito acerca da metade da população brasileira). A forma que encontrei para enfrentar esse ataque impetrado pelo mercado musical e dar minha contribuição no sentido de fomentar o senso crítico das pessoas foi justamente incentivando a escuta livre, desvencilhada de padrões e expectativas preconcebidas. Para tanto, o hábito de, em cada encontro, ouvir programas de rádio concebidos com essa finalidade, a audição contextualizada e a prática criativa de diferentes estilos musicais têm sido minhas principais ferramentas de trabalho e com resultados promissores.

Pude constatar que meus alunos abdicaram de ouvir sempre o mesmo cantor ou conjunto - a "banda" - como eles diziam. Em vez disso, eles têm buscado por novidades e dado mais valor a artistas locais, não se prendendo tanto ao que lhes é passado como sendo a tendência mais recente, ou "moda nacional". Percebi isso ao levar para as aulas, alguns materiais em áudio e vídeo sobre Chiquinho do Acordeon ${ }^{14}$, natural de Santa Cruz do Sul e grande expoente da música instrumental brasileira. Para minha surpresa, nenhum dos alunos o conhecia. Ao ouvirmos parte de sua obra e assistirmos ao documentário $O$ milagre de Santa Luzia: Chiquinho do Acordeon, veio à tona uma quantidade de nomes de artistas naturais de Santa Cruz do Sul ou que ali iniciaram carreira. Este simples conhecimento deu aos alunos muito mais confiança em si próprios como ingressantes no mundo da música. Eles se deram conta de que boa música e bons músicos podem surgir mesmo em pequenas localidades e não apenas nas grandes cidades ou, pior, no exterior.

Para o educador que deseja se aventurar pela a escuta livre, aconselho-o a ter paciência e perseverança. Bem trabalhada e conduzida, essa prática tem tudo para dar resultados surpreendentes. Como atividades auxiliares, o educador pode e deve levar seus alunos a peças teatrais, concertos e recitais, além de propor a simples tarefa de ouvir sons ambientes, sons

\footnotetext{
${ }^{14}$ Romeu Seibel (1928-1993), mais conhecido como Chiquinho do Acordeom, foi acordeonista notável para o desenvolvimento e popularização de seu instrumento no Brasil. Tornou-se muito conhecido por sua técnica refinada e leitura fluente. Chiquinho atuou e gravou com grande número de artistas, com especial destaque para as gravações do quinteto do também gaúcho Radamés Gnattali.
} 
POHLMANN, K. R.; GAVA, J. E.

que estão à nossa volta, sons naturais. Esses sons podem se transformar em matéria prima ou mesmo fornecer ideias para futuras composições musicais. A escuta liberta provoca as mais variadas sensações e dá uma ideia de quão infinitas são as possibilidades colocadas à disposição do compositor de ouvidos abertos, libertos para o mundo.

A criação de qualquer novo hábito pressupõe uma ação inicial. Sendo assim, cabe ao educador musical dar a oportunidade para o novo, incitar a criação, abrir a percepção dos alunos e de si mesmo para novas sonoridades independentemente de modelos preconcebidos ou preocupações com aceitação ou recusa por parte do outro.

Como fechamento, creio ser válido relembrar a célebre frase de Paul Valéry a respeito de sua produção literária: "quando me perguntam o que quis dizer com um poema respondo que não quis dizer, quis fazer e a intenção me fez dizer o que eu disse" (VALÉRY apud FRATUCE PIMENTEL, 2011, p. 5). Parafraseando-o eu diria que quando me perguntam o que quis dizer quando toquei uma nota, respondo que não quis dizer, quis tocar e essa intenção fez soar o que toquei.

\title{
FOR A FREE LISTENING
}

\begin{abstract}
This article discusses the free music listening, which promotes musical knowledge and listening to the widest range of music, releasing the listener, even if partially, with respect to musical repertoires publicized and praised by the mass communication media. As a theoretical foundation and starting point are considered here the works of Murray Schafer about ear cleaning and Gaston Bachelard about the notion of habit. From these authors in particular and teaching experiences reported here, are summed up here techniques and strategies to implement and encourage alternative forms of freer and mindful music listening.
\end{abstract}

Keywords: Music; Education; Free Listening; Habit; Musicaos - Música Sem Fronteiras

PARA UNA ESCUCHA LIBRE

Resumen 
En este artículo se discute el concepto de escuchar música libremente, cuya intención es promover el conocimiento y el oír la más amplia gama de musicas, liberando al oyente, aunque sea parcialmente, con respecto a los repertorios musicales descritas y elogiados por los medios de comunicación de masas. Como fundamento teórico y el punto de partida, considerados aquí están las obras de Murray Schafer sobre la limpieza del oído y Gaston Bachelard acerca de la noción de hábito. A partir de estos autores, en particular, y la enseñanza de experiencias informo aqui esbozo técnicas y estrategias para implementar y promover formas alternativas de escucha musical.

Palabras clave: Música; Educación; Escucha Libre; Hábito; Musicaos - Música Sem Fronteiras

\section{REFERÊNCIAS}

AGUIAR, Wisley Francisco. Música e crítica social em Adorno. Revista Controvérsia, São Leopoldo: Unisinos, vol. 4, jul-dez 2008. Disponível em: http://revistas.unisinos.br/index.php/controversia/article/view/6745. Acesso em: 26 jan. 2014.

BACHELARD, Gaston. A intuição do instante. Campinas: Verus, 2007.

BARBOSA, E.; BULÇÃO, M. Bachelard: pedagogia da razão, pedagogia da imaginação. Petrópolis: Vozes, 2004.

CERQUEIRA, Daniel Lemos. Um enfoque musical sobre a música na mídia. S/d. Disponível em: http://musica.ufma.br/prof/trab/p_dan_enfoquemusicalmusicamidia.pdf. Acesso em 26 jan. 2014.

FRATUCE PIMENTEL, Brutus Abel. O ideário poético de Paul Valéry. Disponível em http://www.abralic.org.br/anais/cong2011/AnaisOnline/resumos/TC0378-1.pdf. Acesso em 14 out. 2013.

GALIMBERTI, Humberto. Psiche e Techne: o homem na idade da técnica. São Paulo: Paulus, 2006.

IAZZETTA, Fernando. $O$ que é música (hoje). In: FÓRUM CATARINENSE DE MUSICOTERAPIA, 1.; 2001, Florianópolis. Anais do I Fórum Catarinense de Musicoterapia. Florianópolis: editora, set. 2001, p. 1-5. 
POHLMANN, K. R.; GAVA, J. E.

LARROSA, Jorge. Notas sobre a experiência e o saber de experiência. Revista Brasileira de Educação, Rio de Janeiro: ANPed $\mathrm{n}^{\circ}$ 19, jan/fev/mar/abr 2002. Disponível em: http://www.scielo.br/scielo.php?script=sci_arttext\&pid=S1413-24782002000100003\&lng=en

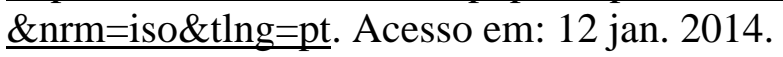

SCHAFER, Murray. A afinação do mundo: uma exploração pioneira pela história e pelo atual estado do mais negligenciado aspecto do nosso ambiente: a paisagem sonora. São Paulo: UNESP, 2001.

O Ouvido Pensante. São Paulo: UNESP, 1991.

Data de recebimento: $28 / 01 / 2014$

Data de aceite: $19 / 02 / 2014$ 